\title{
New perspectives on rodent models of advanced paternal age: relevance to autism
}

\author{
Claire J. Foldi' ${ }^{1}$ Darryl W. Eyles ${ }^{1,2}$, Traute Flatscher-Bader 1,3, John J. McGrath ${ }^{1,2,4}$ and Thomas H. J. Burne ${ }^{1,2 *}$ \\ Queensland Brain Institute, The University of Queensland, St Lucia, QLD, Australia \\ 2 Queensland Centre for Mental Health Research, The Park Centre for Mental Health, Richlands, QLD, Australia \\ ${ }^{3}$ Queensland Institute of Medical Research, Herston, QLD, Australia \\ ${ }^{4}$ Discipline of Psychiatry, The University of Queensland, St Lucia, QLD, Australia
}

Edited by:

Michael J. Meaney, Douglas

Hospital-McGill University, Canada

\section{Reviewed by:}

Fabricio A. Pamplona, University of

Cambridge, UK

Gregg Stanwood, Vanderbilt University, USA

\section{${ }^{*}$ Correspondence:}

Thomas H. J. Burne, Queensland Brain Institute, University of Queensland,

St Lucia, QLD 4076, Australia.

e-mail:t.burne@uq.edu.au
Offspring of older fathers have an increased risk of various adverse health outcomes, including autism and schizophrenia. With respect to biological mechanisms for this association, there are many more germline cell divisions in the life history of a sperm relative to that of an oocyte. This leads to more opportunities for copy error mutations in germ cells from older fathers. Evidence also suggests that epigenetic patterning in the sperm from older men is altered. Rodent models provide an experimental platform to examine the association between paternal age and brain development. Several rodent models of advanced paternal age (APA) have been published with relevance to intermediate phenotypes related to autism. All four published APA models vary in key features creating a lack of consistency with respect to behavioral phenotypes. A consideration of common phenotypes that emerge from these APA-related mouse models may be informative in the exploration of the molecular and neurobiological correlates of APA.

\section{AUTISTIC SPECTRUM DISORDER}

Autistic spectrum disorder (ASD) represents a group of poorly understood disorders with complex etiologies, confounded by substantial clinical and genetic heterogeneity. Males are affected four times as often as females (Chakrabarti and Fombonne, 2005) with a population prevalence of $0.6-0.7 \%$ (Szatmari et al., 2007; Geschwind, 2008). Autism is broadly defined as a neurodevelopmental syndrome with markedly abnormal or impaired development in social interaction and communication, and involving repetitive or restricted patterns of behavior (DSM-IV). Diagnosis depends on clinical recognition of these behavioral symptoms. ASD also includes atypical autism, Asperger's syndrome, Rett syndrome, overactive disorder, and pervasive developmental disorders, all of which are etiologically related to autism (Reichenberg et al., 2006). Although the neurobiology of ASD is not completely understood, one key neurobiological feature of ASD is early brain overgrowth, which is thought to reflect defects in neural patterning and wiring (Courchesne et al., 2007).

While the etiology of ASD remains unknown, twin and family studies have supported a significant genetic contribution to the disorder. The concordance rates for autism and ASD in monozygotic (MZ) twins are 70 and $90 \%$, respectively, compared to the dizygotic (DZ) concordance rates of 5 and 10\% (Sebat et al., 2007). Rett syndrome is a rare form of ASD that arises from mutations in the methyl-CpG-binding protein-2 (MeCP2) gene (Monteggia and Kavalali, 2009). However, ASD displays considerable heterogeneity and the recent large collaborative genome scan by the Autism Genome Project (AGP) of nearly 1200 sibling pairs with ASD identified several regions of interest, yet failed to identify one region with genome-wide significance (Szatmari et al., 2007). The genetic contribution to ASD etiology is thus likely to involve subtle alterations including rare single nucleotide polymorphisms (SNP) or changes in copy-number variation (CNV). CNV represents a gain (duplication) or loss (deletion or inversion) in a chromosomal region greater than $1 \mathrm{~kb}$ in size. With approximately $12 \%$ of the human genome varying in copy number (Carter, 2007), CNVs contribute significantly to genetic heterogeneity. A recent surge of research has revealed associations between CNVs and autism, including both duplications and deletions (Berg et al., 2007; Sebat et al., 2007; Weiss et al., 2008; Xu et al., 2008; Cho et al., 2009; Glessner et al., 2009; Guilmatre et al., 2009).

In addition to genetic variation, several other factors have been identified from epidemiological studies, which increase the risk for ASD diagnosis, including obstetric complications, such as preeclampsia (Mann et al., 2010), premature birth or low birth weight (Eaton et al., 2001), and advanced paternal age (APA; Reichenberg et al., 2006). APA is a risk factor identified by epidemiology that is potentially modifiable, and thus represents a rare target for ASD research.

\section{ADVANCED PATERNAL AGE}

Advanced paternal age is associated with a broad range of disease outcomes in children, ranging from an increased risk for neural tube defects and cleft palate (McIntosh et al., 1995), intellectual impairments (Malaspina et al., 2005; Saha et al., 2009), epilepsy (Vestergaard et al., 2005), and bipolar disorder (Frans et al., 2008). The most robust and replicated studies in this field have demonstrated a link between APA and elevated risk for the neurodevelopmental disorders autism (for example, Reichenberg et al., 2006; Durkin et al., 2008; Tsuchiya et al., 2008; Lundstrom et al., 2010; Shelton et al., 2010) and schizophrenia (Malaspina et al., 2001; Brown et al., 2002; Dalman and Allebeck, 2002; Byrne et al., 2003; El-Saadi et al., 2004; Tsuchiya et al., 2005). One study assessed a cohort of 132,271 individuals and found that children of men aged 
40 years or older had a nearly six-fold increased risk of ASD compared to the children of men aged 30 years or younger (Reichenberg et al., 2006). This finding has been replicated in a large, populationbased Danish study (Larsson et al., 2005). In recent years several large US studies (some of which may include overlapping cases) have also reported an association between APA and increased risk of ASD (Croen et al., 2007; Durkin et al., 2008; Grether et al., 2009; Shelton et al., 2010).

\section{BIOLOGICAL MECHANISMS UNDERPINNING APA AND RISK OF AUTISM}

Advanced paternal age represents an opportunity to investigate gene and environment interactions with the potential to help understand how de novo mutation events occur and contribute to disorders such as ASD (Malaspina, 2001; Sebat et al., 2007). However, the molecular mechanisms underlying the effects of APA on disease outcomes in children remain essentially unknown. A large number of factors influences human development and could covary with paternal age, one of which is maternal age (Saha et al., 2009). Most attention to date has focused on the effects of aging on the integrity of germ cells, because mammalian germ cell development differs between males and females. A greater number of germ line cell divisions occur in the sperm relative to the egg and the disparity between the quantity of male and female divisions increases with age. With respect to humans, only 24 cell divisions are required in the development of an oocyte and 22 of these occur before birth. In contrast, spermatogonia undergo an estimated 30 cell divisions before puberty and then divide every 16 days thereafter. Therefore, the sperm of a 40 -yearold man has undergone over four times as many replications than that of a 20-year-old. Each time these cells divide, the replication of the genome increases susceptibility to copy error mutations (Crow, 2000). APA-related copy error is likely to result in rare mutations in individual sperm. This suggests that such copy error could contribute to changes in structural variation, such as CNVs. Therefore, one challenge lies in the clarification of an association between APA and an increase in CNVs using a suitable model system.

Dysregulation of epigenetic processes during spermatogenesis in older men also has the potential to contribute to the association between APA and neurocognitive disorders (Perrin et al., 2007). Changes in chromatin packaging and integrity (Zubkova and Robaire, 2006) and hypermethylation in ribosomal DNA (Oakes et al., 2003) were evident in spermatozoa of older rats when compared to younger rats. Further, it is possible that agerelated alterations in gene imprinting mediate APA effects on the next generation. Usually genes are expressed from both paternal alleles. For imprinted genes, only one of the alleles is transcribed, the other allele is represented in a parent-of-origin dependent manner (Surani, 1998; Reik and Walter, 2001). Within the genome, the majority of imprinted genes occur in large clusters controlled by imprinting centers (Koerner and Barlow, 2010). In some instances, imprinted gene expression can be tissue-specific and within the brain it may occur in a region or cell-specific manner (Davies et al., 2004; Gregg et al., 2010a,b). Changes to the expression of imprinted genes may alter brain development (Gregg et al., 2010b) and have been connected with neurocognitive disease (Davies et al., 2004; Isles et al., 2006; Perrin et al., 2007). Perrin et al. (2007) suggests that APA could increase the likelihood of epimutations or mutations within imprinted genes or imprinting centers. The next challenge is, therefore, to develop an animal model to test the hypothesis that APA can directly alter epigenetic processes.

There is some indirect evidence from clinical research to support the hypothesis that these APA-related mechanisms may be implicated in ASD. Genetic studies indicate that CNVs are significantly more common in ASD (Sebat et al., 2007; Christian et al., 2008; Marshall et al., 2008; Merikangas et al., 2009; Weiss and Arking, 2009; Pinto et al., 2010). Rett syndrome, an X chromosome-linked $\mathrm{ASD}$, has been associated with mutations in $\mathrm{MeCP} 2$ gene encoding a protein with key functions in the regulation of epigenetic patterning (Nagarajan et al., 2008; Feinberg, 2010; Gonzales and LaSalle, 2010).

Furthermore, loss of methylation at the maternally imprinted insulin-like growth factor II (IGF2) gene was associated with APA in cord blood cells of Chinese subjects (Dai et al., 2007). Interestingly, the levels of this growth hormone were elevated in blood of boys with ASD or autism and this may have contributed to the larger head circumference and body mass index seen in these boys (Mills et al., 2007). Moreover, global methylation profiling of lymphoblastoid cell lines from monozygotic twins discordant for autism showed altered methylation in promoters for several candidate genes previously linked to autism (Nguyen et al., 2010). However, it is difficult to differentiate between cause and effect in these studies.

The molecular mechanisms described above may not be mutually exclusive but they may interact with each other to increase the risk of developing ASD (Schanen, 2006). Thus, the one commonly recurrent cytogenetic aberration associated with ASD entails duplications of chromosome 15q11-13, which occur in up to $5 \%$ of patients with ASD (Cook et al., 1997, 1998; Schroer et al., 1998). The affected region includes paternally and maternally imprinted genes and maternally derived duplications confer an 85\% increase in the risk of developing ASD (Cook et al., 1997). Genome-wide expression profiling using lymphoblasts from ASD patients with duplications in this region identified over 100 consistently differentially expressed transcripts, but most of this arose from genes outside the duplication (Baron et al., 2006). These observations emphasize the notion that the autism phenotype is an incompletely penetrant, multigenic trait.

\section{ANIMAL MODELS}

Although clinical research is clearly important, testing causative and mechanistic hypothesis is difficult in humans because multiple genetic and environmental factors are involved in the etiology of ASD. Animal models that focus on behavioral dimensions associated with underlying biological mechanisms are valuable for this purpose. However, many core behavioral symptoms of ASD include aspects that may be impossible to model in mice. For example, theory of mind, which is the ability to empathize with the feelings and intentions of others, as well as language deficits are not easily evaluated in the mouse. Therefore, ASD may be particularly difficult to model in rodents (Crawley, 2007). In contrast, social behavior can be effectively assessed in mouse models, because mice are known to engage in high levels of social interaction and social communication (Gheusi et al., 1994).

Three broad types of approach have been used in mouse models of autism. The first of these used targeted disruption or mutation of genes that may be involved in ASD susceptibility, such as the Fmr1 
gene that is associated with Fragile X syndrome (McNaughton et al., 2008). The drawback of this approach is that the targeted allele in the mouse may be functionally distinct from the allele present in the ASD population (Moy et al., 2006). A second approach has been to generate models based on defects in neurotransmission, such as neonatal serotonin depletion, or alterations in parts of the serotonin signaling pathway (Moy and Nadler, 2008). The third major approach to modeling autism in the mouse has been based on known epidemiological risk factors such as APA. This is an emerging area of animal modeling that correlates naturalistically with disease etiology in humans.

\section{ANIMAL MODELS OF APA}

The first rodent study investigating the consequences of APA on adult behavior assessed the offspring of 2.5-23 month-old male Wistar rats on measures of spontaneous activity and learning capacity in a conditioned avoidance task (Auroux, 1983). This study revealed a significant decrease in learning capacity in male and female offspring with increasing paternal age. This learning deficit was seen in male offspring of sires that were 6 months of age or older, but only became apparent in female offspring when the sires were 18 months old. While the Auroux (1983) study showed a cognitive defect resulting from APA in the rat, inbred mouse strains are preferred for this type of research. The use of inbred strains minimizes genetic variability in order to optimize the dissection of potential genetic and epigenetic mechanisms underlying APA. Additionally, the genome of the inbred mouse provides the opportunity for genetic manipulation to test specific hypotheses.

When generating new models of complex psychiatric disease, it is difficult to decide the most appropriate conditions for the model. For example, at what age is a mouse considered of "advanced age?" The longevity of laboratory mice varies substantially by strain and laboratory. While male C57BL/6J mice have an average life span of 28.5 months (Massie et al., 1991); non-representative animals that live for extended periods influence this measure. The Jackson Laboratory (http://jaxmice.jax.org/strain/000664.html) notes that the median age span for C57 is approximately 20 months. If a naturalistic model is preferred, then one would select sires for APA models as close to the age at which there is a known APA effect on psychiatric illness in humans. For autism and schizophrenia, this is $40-50$ years in the human (Malaspina et al., 2001; Reichenberg et al., 2006), which is equivalent to $12-15$ months in the mouse (or 16-20 months in the rat).

To date, there are three published models investigating the behavioral effects of APA in the mouse. Table 1 depicts the behavioral phenotypes and specific features of each of these models. The first study investigated the effects of APA on spontaneous activity and passive avoidance learning in adult offspring from a hybrid (C57BL/6JIco x CBA/JIco) mouse strain (Garcia-Palomares et al., 2009). These authors demonstrated a learning deficit in the offspring of sires aged 25 and 30 months, compared to the offspring of sires 3 months old, and a decrease in motor activity. However, this reduced activity was only found in the offspring of extremely old sires (the 30-month-old group). Only 5 sires out of 20 survived at this age and as such, may have contributed less variation than from the other age groups (all comprising 20 sires). Thus, the behavioral phenotype in this model could be a result of a combination APA and unusual paternal longevity.

A second mouse model of APA utilized the inbred C57BL/6J strain to examine APA effects on social and exploratory behaviors in the offspring of 2 month-old and 10 month-old sires (Smith et al., 2009). They reported less engagement in social activity and reduced exploratory behavior for the offspring of older sires. However, locomotion was not altered in this model, as seen in the Garcia-Palomares et al. (2009) study, and no other behavioral domains were examined.

Table 1 | Behavioral phenotype in offspring of rodent APA models.

\begin{tabular}{|c|c|c|c|c|c|}
\hline Study & Year & Strain/species & APA sire age & Behaviors examined & Outcomes \\
\hline \multirow[t]{3}{*}{ Auroux (1983) } & 1983 & Wistar Rat & 23 months & Avoidance learning & $\downarrow$ \\
\hline & & & & Emotionality & - \\
\hline & & & & Locomotion & - \\
\hline \multirow[t]{2}{*}{ Garcia-Palomares et al. (2009) } & 2009 & C57BL/6Jlco x CBA/Jlco mouse & 25-30 months & Avoidance learning & $\downarrow$ \\
\hline & & & & Locomotion & $\downarrow$ \\
\hline \multirow[t]{3}{*}{ Smith et al. (2009) } & 2009 & C57BL/6J mouse & 10 months & Social behavior & $\downarrow$ \\
\hline & & & & Exploration & $\downarrow$ \\
\hline & & & & Locomotion & - \\
\hline \multirow[t]{8}{*}{ Foldi et al. (2010) } & 2010 & C57BL/6J mouse & 12-18 months & Neurological function & - \\
\hline & & & & Anxiety & $\uparrow$ \\
\hline & & & & Exploration & $\uparrow$ \\
\hline & & & & Social behavior & - \\
\hline & & & & Locomotion & - \\
\hline & & & & Learned helplessness & $\downarrow$ \\
\hline & & & & Acoustic startle & - \\
\hline & & & & Prepulse inhibition & - \\
\hline
\end{tabular}

$\uparrow=$ APA resulted in a significant increase in this behavior.

$\downarrow=$ APA resulted in a significant decrease in this behavior.

$-=$ APA did not alter this behavior. 
The third APA mouse model developed by our group uses 4 month-old (control) and 12-18 month-old (APA) sires of the inbred C57BL/6J strain (Foldi et al., 2010). APA sire ages were selected because they best match the at-risk relative age in humans. Sires were mated with 4 month-old females and adult offspring were examined on a comprehensive battery of behavioral tests, designed to assess the broad domains of anxiety, exploration, locomotion, learned helplessness, sensorimotor gating, and working and spatial memories. Following behavioral phenotyping, the brains of these mice were imaged ex vivo on a 16.4T MRI scanner. Brain morphology was also examined at birth in a separate cohort of animals. The behavioral phenotype of APA mice in our study included a significant increase in anxiety-related behavior and exploration and an altered coping strategy to an aversive environment (the Forced Swim test). In contrast to the Garcia-Palomares et al. (2009) study, we showed no alterations in locomotion or learning, although different paradigms were used to assess learning in both studies. Also in contrast with the Smith et al. (2009) study, social behavior in APA mice was normal and exploration was increased, not decreased. The trajectory of cortical development was also altered for male APA mice, in that as neonates, APA males had significantly thinner cortices than did control males. This appeared to reverse by adulthood in that the cortical volumes of male APA mice were now significantly larger than control male mice. This volumetric increase was specific to the rostral portion of the cortex (i.e., rostral to the lateral ventricles; Foldi et al., 2010). Our study remains the only published model of APA to investigate brain structural outcomes. The altered pattern of cortical growth in APA mice is of particular relevance to the association between APA and autism. The cortices of APA neonates were thinner than those of controls, indicating that APA altered the trajectory of cortical development in this model. The cerebral cortex in the brain of a neonatal mouse is similar to that of a late second trimester or early third trimester human fetus (Clancy et al., 2001). This pattern of cortical development may be similar to indices of brain growth in children with autism. Although head circumference is only a proxy marker of brain size, head circumference in children who develop autism is slightly smaller at birth but the growth in circumference accelerates abnormally 6-21 months after birth (Courchesne et al., 2003; Dementieva et al., 2005). Neuroimaging studies have also suggested that autism is associated with rapid and excessive brain growth in the first years of life, resulting in increased cortical volume at 2-4 years of age (Courchesne et al., 2001; Sparks et al., 2002). Furthermore, cerebral overgrowth in autism is greatest in the frontal and temporal cortices (Carper and Courchesne, 2005), which is consistent with the neuroanatomical findings described in APA mice by Foldi et al. (2010). Therefore, in terms of brain morphology, our APA mouse model seems to recapitulate part of the structural neurobiology of autism. In addition, the anatomical changes were observed only in male APA offspring, with no alterations shown for female mice. Considering the marked excess of autism in males [11] this further supports the relevance of our model to the disorder.

While there remains a lack of consistency in the behavioral phenotypes of these three APA-related mouse models, there are important differences in how they are constituted. Importantly, the age of the APA sires used for each study varied (see Table 1).
It is known that behavioral phenotypes are markedly affected by housing and testing conditions, even when significant precautions are taken to equate test apparatus, protocols, and other features of animal husbandry (Crabbe et al., 1999). So perhaps it is unsurprising that the reported APA phenotypes differ so significantly, considering inconsistencies in both animal husbandry and testing techniques. What is also obvious from comparing phenotypes is that APA in the mouse is not associated with rare outliers, but results in shifts in various behavioral outcomes that are significant at the population level. One would presume that if we were dealing with a model of rare, dominant de novo genetic events, that this would result in qualitative alterations in phenotype, rather than quantitative population-level effects. Alternately it may be that because these population-level effects are in such non-selective behaviors, that they are the result of a cumulative effect of different rare mutations or CNVs that impact on the same behaviors. The instability of the phenotype may also simply reflect the broad associations with disease outcomes in human populations.

It is possible that offspring behavioral phenotypes are altered by non-genetic transmission of paternal characteristics, such as paternal behavior. One study has explored the strength of paternaloffspring open-field behavior correlations, based on the length of sire exposure (LSE) prenatally (Alter et al., 2009). This study demonstrated stronger correlations when sires were housed with pregnant females (dams) for longer durations. LSE could impact offspring development via maternal stress, such as by altering maternal hormone levels (Lupo Di Prisco et al., 1978) or other variation in male phenotypic qualities (Drickamer et al., 2000). We have recently shown that prenatal LSE alone does not influence behavioral outcomes in offspring, by comparing the two predominant methods for breeding laboratory mice. The offspring of both pair-housed and time-mated breeding dyads had equivalent behavioral phenotypes (Foldi et al., 2011). However, the effects of preconception and prenatal paternal behavior may be highlighted when variables such as paternal drug exposure are included. For example, paternal cocaine abuse in mice prior to coitus has been shown to decrease attention and working memory in offspring (He et al., 2006). Whether the reported APA rodent phenotypes are affected by the postnatal presence or absence of the sire remains unknown, since these four studies removed the sires prior to birth. However, considering the behavioral changes in older mice (Strong et al., 1980; Frick et al., 2000), it is plausible that sire behavior would contribute to offspring phenotypes.

It may also be that naturalistic models are not appropriate. The hypothesized mechanism of APA involves rare genetic events, affecting only a small percentage of offspring. Perhaps the field needs to move into a model where rare mutations can be detected in very large populations, for example in Drosophila (Burne et al., 2011). Additionally, it may be that a reliable phenotype only becomes apparent in the offspring of extremely old male mice, as was seen in the Garcia-Palomares (2009) study. Thus, the next generation of APA mouse models should utilize an APA "dose" design (e.g., 12,18 , and 24 months. This will ascertain firstly, whether increased APA in the mouse produces an increased phenotypic difference and secondly, whether APA "dose" can explain the disparity within the three published behavioral phenotypes. Regardless, the APA mouse model will allow the exploration of within-mouse correlations 
between behavioral, neuroanatomical, and genomic outcomes. In many instances it will be possible to correlate brain structure versus behavior in the same animal, and behavioral and brain structural outcomes versus genome-wide assessment of methylation and/ or copy-number variants in the same animal. In some respects, the APA model, which is based on age-related mutagenesis, represents a naturalistic forward genetics platform. Traditionally such platforms use chemicals to induce mutations in sperm stem cells and then use selective breeding on phenotypes of interest to map genotype-phenotype relationships (Kile and Hilton, 2005; Caspary and Anderson, 2006).

\section{CONCLUSION}

The offspring of older fathers have an increased risk of various adverse health outcomes, including autism and schizophrenia. While the molecular mechanisms underpinning these associations are unclear, potential candidates include CNVs and epigenetics. These mechanisms are not mutually exclusive factors but

\section{REFERENCES}

Alter, M. D., Gilani, A. I., Champagne, F. A., Curley, J. P., Turner, J. B., and Hen, R. (2009). Paternal transmission of complex phenotypes in inbred mice. Biol. Psychiatry 66, 1061-1066.

Auroux, M. (1983). Decrease of learning capacity in offspring with increasing paternal age in the rat. Teratology 27, 141-148.

Baron, C. A., Tepper, C. G., Liu, S. Y., Davis, R. R., Wang, N. J., Schanen, N. C., and Gregg, J. P. (2006). Genomic and functional profiling of duplicated chromosome 15 cell lines reveal regulatory alterations in UBE3A-associated ubiquitin-proteasome pathway processes. Hum. Mol. Genet. 15, 853-869.

Berg, J. S., Brunetti-Pierri, N., Peters, S. U., Kang, S. H. L., Fong, C. T., Salamone, J., Freedenberg, D., Hannig, V. L., Prock, L. A., Miller, D. T., Raffalli, P., Harris, D. J., Erickson, R. P., Cunniff, C., Clark, G. D., Blazo, M. A., Peiffer, D. A., Gunderson, K. L., Sahoo, T., Patel, A., Lupski, J. R., Beaudet, A. L., and Cheung, S. W. (2007). Speech delay and autism spectrum behaviors are frequently associated with duplication of the 7q11.23 Williams-Beuren syndrome region. Genet. Med. 9, 427-441.

Bray, I., Gunnell, D., and Smith, G. D. (2006). Advanced paternal age: how old is too old? J. Epidemiol. Community Health 60, 851-853.

Brown, A. S., Schaefer, C. A., Wyatt, R. J., Begg, M. D., Goetz, R., Bresnahan, M. A., Harkavy-Friedman, J., Gorman, J. M., Malaspina, D., and Susser, E. S. (2002). Paternal age and risk of schizophrenia in adult offspring. Am. J. Psychiatry 159, 1528-1533.

Burne, T., Scott, E., Van Swinderen, B., Hilliard, M., Reinhard, J., Claudianos, C., Eyles, D., and Mcgrath, J. (2011).
Big ideas for small brains: what can psychiatry learn from worms, flies, bees and fish? Mol. Psychiatry 16,7-16. Byrne, M., Agerbo, E., Ewald, H., Eaton, W. W., and Mortensen, P. B. (2003). Parental age and risk of schizophrenia - a case-control study. Arch. Gen. Psychiatry 60, 673-678.

Carper, R. A., and Courchesne, E. (2005). Localized enlargement of the frontal cortex in early autism. Biol. Psychiatry 57, 126-133.

Carter, N. P. (2007). Methods and strategies for analyzing copy number variation using DNA microarrays. Nat. Genet. 39, S16-S21.

Caspary, T., and Anderson, K. V. (2006). Uncovering the uncharacterized and unexpected: unbiased phenotypedriven screens in the mouse. Dev. Dyn. 235, 2412-2423.

Chakrabarti, S., and Fombonne, E. (2005). Pervasive developmental disorders in preschool children: confirmation of high prevalence. Am. J. Psychiatry 162, 1133-1141.

Cho, S. C., Yim, S. H., Yoo, H. K., Kim, M. Y., Jung, G. Y., Shin, G. W., Kim, B. N., Hwang, J. W., Kang, J. J., Kim, T. M., and Chung, Y. J. (2009). Copy number variations associated with idiopathic autism identified by whole-genome microarray-based comparative genomic hybridization. Psychiatr. Genet. 19, 177-185.

Christian, S. L., Brune, C. W., Sudi, J., Kumar, R. A., Liu, S., Karamohamed, S., Badner, J. A., Matsui, S., Conroy, J., Mcquaid, D., Gergel, J., Hatchwell, E., Gilliam, T. C., Gershon, E. S., Nowak, (2008). Novel submicroscopic chromosomal abnormalities detected in autism spectrum disorder. Biol. Psychiatry 63, 1111-1117. N. J., Dobyns, W. B., and Cook, E. H.

could combine and interact to produce an altered neurocognitive phenotype. While there are only four published rodent models of APA, the phenotypes differ substantially between these models. This is an emerging area of research and future animal studies will need to refine the behavioral and structural phenotype to further explore genetic and epigenetic mechanisms that may underlie these changes. APA models might not only provide clues to upstream mechanisms of action in ASD, but could serve as screening platforms for treatments. The urgency for the research community to understand the effects of APA are becoming increasingly important given current trends toward delaying parenting (Bray et al., 2006; Toriello and Meck, 2008).

\section{ACKNOWLEDGMENTS}

The authors are grateful for support from Queensland Health and the National Health and Medical Research Council of Australia. We thank Prof. E. Whitelaw and Dr S. Chong for valuable comments on the manuscript.

Clancy, B., Darlington, R. B., and Finlay, B. L. (2001). Translating developmental time across mammalian species. Neuroscience 105, 7-17.

Cook, E. H., Courchesne, R. Y., Cox, N. J., Lord, C., Gonen, D., Guter, S. J., Lincoln, A., Nix, K., Haas, R., Leventhal, B. L., and Courchesne, E. (1998). Linkage-disequilibrium mapping of autistic disorder, with 15q1113 markers. Am. J. Hum. Genet. 62 1077-1083.

Cook, E. H., Lindgren, V., Leventhal, B. L., Courchesne, R., Lincoln, A., Shulman, C., Lord, C., and Courchesne, E. (1997). Autism or atypical autism in maternally but not paternally derived proximal $15 \mathrm{q}$ duplication. Am. J. Hum. Genet. 60, 928-934.

Courchesne, E., Carper, R., and Akshoomoff, N. (2003). Evidence of brain overgrowth in the first year of life in autism. JAMA 290, 337-344.

Courchesne, E., Karns, C. M., Davis, H. R., Ziccardi, R., Carper, R. A., Tigue, Z. D., Chisum, H. J., Moses, P., Pierce, K., Lord, C., Lincoln, A. J., Pizzo, S., Schreibman, L., Haas, R. H., Akshoomoff, N. A., and Courchesne, R. Y. (2001). Unusual brain growth patterns in early life in patients with autistic disorder - an MRI study. Neurology 57, 245-254.

Courchesne, E., Pierce, K., Schumann, C. M., Redcay, E., Buckwalter, J. A., Kennedy, D. P., and Morgan, J. (2007). Mapping early brain development in autism. Neuron 56, 399-413.

Crabbe, J. C., Wahlsten, D., and Dudek, B. C. (1999). Genetics of mouse behavior: interactions with laboratory environment. Science 284, 1670-1672.

Crawley, J. N. (2007). Mouse behavioral assays relevant to the symptoms of autism. Brain Pathol. 17, 448-459.
Croen, L. A., Najjar, D. V., Fireman, B., and Grether, J. K. (2007). Maternal and paternal age and risk of autism spectrum disorders. Arch. Pediatr. Adolesc. Med. 161, 334-340.

Crow, J. F. (2000). The origins patterns and implications of human spontaneous mutation. Nat. Rev. Genet. 1, 40-47.

Dai, Y. M., Wang, Z. Q., Li, J., Gu, X. F. Zheng, M. M., Zhou, J. J., Ye, X. D., Yao, J. C., Cui, I., Hu, Y. L., and Cui, H. M. (2007). Imprinting status of IGF2 in cord blood cells of Han Chinese newborns. Int. J. Mol. Sci. 8, 273-283.

Dalman, C., and Allebeck, P. (2002). Paternal age and schizophrenia: further support for an association. Am. J. Psychiatry 159, 1591-1592.

Davies, W., Smith, R. J., Kelsey, G., and Wilkinson, L. S. (2004). Expression patterns of the novel imprinted genes Nap115 and Peg13 and their nonimprinted host genes in the adult mouse brain. Gene Expr. Patterns 4, 741-747.

Dementieva, Y.A., Vance, D. D., Donnelly, S. L., Elston, L. A., Wolpert, C. M., Ravan, S.A., Delong, G. R., Abramson, R. K., Wright, H. H., and Cuccaro, M. L. (2005). Accelerated head growth in early development of individuals with autism. Pediatr. Neurol. 32, 102-108.

Drickamer, L. C., Gowaty, P. A., and Holmes, C. M. (2000). Free female mate choice in house mice affects reproductive success and offspring viability and performance. Anim. Behav. 59, 371-378.

Durkin,M.S., Maenner,M.J., Newschaffer, C. J., Lee, L. C., Cunniff, C. M., Daniels, J. L., Kirby, R. S., Leavitt, L., Miller, L., Zahorodny, W., and Schieve, L. A. (2008).Advanced parental age and the risk of autism spectrum disorder. Am. J. Epidemiol. 168, 1268-1276. 
Eaton, W.W., Mortensen, P. B., Thomsen, P. H., and Frydenberg, M. (2001). Obstetric complications and risk for severe psychopathology in childhood. J. Autism Dev. Disord. 31, 279-285.

El-Saadi, O., Pedersen, C. B., Mcneil, T. F., Saha, S., Welham, J., O'callaghan, E., Cantor-Graae, E., Chant, D., Mortensen, P. B., and Mcgrath, J. (2004). Paternal and maternal age as risk factors for psychosis: findings from Denmark, Sweden and Australia. Schizophr. Res. 67, 227-236.

Feinberg, A. P. (2010). Genome-scale approaches to the epigenetics of common human disease. Virchows Arch. 456, 13-21.

Foldi, C. J., Eyles, D. W., Mcgrath, J. J., and Burne, T.H. J. (2010). Advanced paternal age is associated with alterations in discrete behavioural domains and cortical neuroanatomy of C57BL/6J mice. Eur. J. Neurosci. 31, 556-564.

Foldi, C. J., Eyles, D. W., Mcgrath, J. J., and Burne, T. H. J. (2011). The effects of breeding protocol in C57BL/6 mice on adult offspring behaviour. PLoS ONE 6, e18152. doi: 10.1371/journal. pone. 0018152

Frans, E. M., Sandin, S., Reichenberg, A., Lichtenstein, P., Langstrom, N., and Hultman, C. M. (2008). Advancing paternal age and bipolar disorder. Arch. Gen. Psychiatry 65, 1034-1040.

Frick, K. M., Burlingame, L. A., Arters, J. A., and Berger-Sweeney, J. (2000). Reference memory, anxiety and estrous cyclicity in C57BL/6NIA mice are affected by age and sex. Neuroscience 95, 293-307.

Garcia-Palomares, S., Pertusa, J. F., Minarro, J., Garcia-Perez, M. A., Hermenegildo, C., Rausell, F., Cano, A., and Tarin, J. J. (2009). Long-term effects of delayed fatherhood in mice on postnatal development and behavioral traits of offspring. Biol. Reprod. $80,337-342$.

Geschwind, D. H. (2008). Autism: many genes, common pathways? Cell 135, 391-395.

Gheusi, G., Bluthe, R. M., Goodall, G., and Dantzer, R. (1994). Social and individual recognition in rodents methodological aspects and neurobiological bases. Behav. Processes 33, 59-87.

Glessner,J.T., Wang, K., Cai, G., Korvatska, O., Kim, C. E., Wood, S., Zhang, H., Estes, A., Brune, C. W., Bradfield, J. P., Imielinski, M., Frackelton, E. C., Reichert, J., Crawford, E. L., Munson, J., Sleiman, P. M., Chiavacci, R., Annaiah, K., Thomas, K., Hou, C., Glaberson, W., Flory, J., Otieno, F., Garris, M., Soorya, L., Klei, L., Piven, J., Meyer, K. J., Anagnostou, E., Sakurai, T., Game, R. M., Rudd,
D. S., Zurawiecki, D., Mcdougle, C. J., Davis, L. K., Miller, J., Posey, D. J., Michaels, S., Kolevzon, A., Silverman, J.M., Bernier, R., Levy, S. E., Schultz, R. T., Dawson, G., Owley, T., Mcmahon, W. M., Wassink, T. H., Sweeney, J. A., Nurnberger, J. I., Coon, H., Sutcliffe, J. S., Minshew, N. J., Grant, S. F., Bucan, M., Cook, E. H., Buxbaum, J. D., Devlin, B., Schellenberg, G. D., and Hakonarson, H. (2009). Autism genome-wide copy number variation reveals ubiquitin and neuronal genes. Nature 459, 569-573.

Gonzales, M. L., and LaSalle, J. M. (2010). The role of MeCP2 in brain development and neurodevelopmental disorders. Curr. Psychiatry Rep. 12, 127-134.

Gregg, C., Zhang, J., Butler, J. E., Haig, D., and Dulac, C. (2010a). Sex-specific parent-of-origin allelic expression in the mouse brain. Science 329, 682-685.

Gregg, C., Zhang, J., Weissbourd, B., Luo, S., Schroth, G. P., Haig, D., and Dulac, C. (2010b). High-resolution analysis of parent-of-origin allelic expression in the mouse brain. Science 329, 643-648.

Grether, J. K., Anderson, M. C., Croen, L. A., Smith, D., and Windham, G. C. (2009). Risk of autism and increasing maternal and paternal age in a large North American population. Am. J. Epidemiol. 170, 1118-1126.

Guilmatre, A., Dubourg, C., Mosca, A. L., Legallic, S., Goldenberg, A., Drouin-Garraud, V., Layet, V., Rosier, A., Briault, S., Bonnet-Brilhault, F., Laumonnier, F., Odent, S., Le Vacon, G., Joly-Helas, G., David, V., Bendavid, C., Pinoit, J. M., Henry, C., Impallomeni, C., Germano, E., Tortorella, G., Di Rosa, G., Barthelemy, C., Andres, C., Faivre, L., Frebourg, T., Saugier Veber, P., and Campion, D. (2009). Recurrent rearrangements in synaptic and neurodevelopmental genes and shared biologic pathways in schizophrenia, autism, and mental retardation. Arch. Gen. Psychiatry 66, 947-956.

He, F., Lidow, I. A., and Lidow, M. S. (2006). Consequences of paternal cocaine exposure in mice. Neurotoxicol. Teratol. 28, 198-209.

Isles, A. R., Davies, W., and Wilkinson, L. S. (2006). Genomic imprinting and the social brain. Philos. Trans. R. Soc. Lond. B Biol. Sci. 361, 2229-2237.

Kile, B. T., and Hilton, D. J. (2005). The art and design of genetic screens: mouse. Nat. Rev. Genet. 6, 557-567.

Koerner, M. V., and Barlow, D. P. (2010). Genomic imprinting-an epigenetic gene-regulatory model. Curr. Opin. Genet. Dev. 20, 164-170.

Larsson, H. J., Eaton, W. W., Madsen, K. M., Vestergaard, M., Olesen, A. V.,
Agerbo, E., Schendel, D., Thorsen, P., and Mortensen, P. B. (2005). Risk factors for autism: perinatal factors, parental psychiatric history, and socioeconomic status. Am. J. Epidemiol. 161, 916-925.

Lundstrom, S., Haworth, C. M. A., Carlstrom, E., Gillberg, C., Mill, J., Rastam, M., Hultman, C. M., Ronald A., Anckarsater, H., Plomin, R. Lichtenstein, P., and Reichenberg, A. (2010). Trajectories leading to autism spectrum disorders are affected by paternal age: findings from two nationally representative twin studies. J. Child Psychol. Psychiatry 51, 850-856.

Lupo Di Prisco, C., Lucarini, N., and Dessi-Fulgheri, F. (1978). Testosterone aromatization in rat brain is modulated by social environment. Physiol. Behav. 20, 345-348.

Malaspina, D. (2001). Paternal factors and schizophrenia risk: de novo mutations and imprinting. Schizophr. Bull. 27 , 379-393.

Malaspina, D., Harlap, S., Fennig, S., Heiman, D., Nahon, D., Feldman, D., and Susser, E. S. (2001). Advancing paternal age and the risk of schizophrenia. Arch. Gen. Psychiatry 58, 361-367.

Malaspina, D., Reichenberg, A., Weiser, M., Fennig, S., Davidson, M., Harlap, S., Wolitzky, R., Rabinowitz, J., Susser, E., and Knobler, H. Y. (2005). Paternal age and intelligence: implications for age-related genomic changes in male germ cells. Psychiatr. Genet. 15, 117-125.

Mann, J. R., Mcdermott, S., Bao, H., Hardin, J., and Gregg, A. (2010). Preeclampsia, birth weight, and autism spectrum disorders. J. Autism Dev. Disord. 40, 548-554.

Marshall, C. R., Noor, A., Vincent, J. B., Lionel, A. C., Feuk, L., Skaug, J., Shago, M., Moessner, R., Pinto, D. Ren, Y., Thiruvahindrapduram, B., Fiebig, A., Schreiber, S., Friedman, J. Ketelaars, C. E. J., Vos, Y. J., Ficicioglu, C., Kirkpatrick, S., Nicolson, R., Sloman, L., Surnmers, A., Gibbons, C. A., Teebi, A., Chitayat, D. Weksberg, R., Thompson, A., Vardy, C., Crosbie, V., Luscombe, S., Baatjes, R., Zwaigenbaum, L., Roberts, W., Fernandez, B., Szatmari, P., and Scherer, S. W. (2008). Structural variation of chromosomes in autism spectrum disorder. Am. J. Hum. Genet. 82, 477-488.

Massie, H. R., Aiello, V. R., and Sternick, S. M. (1991). Comparative survival of C57bl/6j mice on 2 commonly used mouse diets. Age (Omaha) 14, 53-56.

McIntosh, G. C., Olshan, A. F., and Baird, P. A. (1995). Paternal age and the risk of birth defects in offspring. Epidemiology 6, 282-288.

McNaughton, C. H., Moon, J., Strawderman, M. S., Maclean, K. N., Evans, J., and Strupp, B. J. (2008). Evidence for social anxiety and impaired social cognition in a mouse model of Fragile X syndrome. Behav. Neurosci. 122, 293-300.

Merikangas, A. K., Corvin, A. P., and Gallagher, L. (2009). Copy-number variants in neurodevelopmental disorders: promises and challenges. Trends Genet. 25, 536-544.

Mills, J. L., Hediger, M. L., Molloy, C. A., Chrousos, G. P., Manning-Courtney, P., Yu, K. F., Brasington, M., and England, L. J. (2007). Elevated levels of growth-related hormones in autism and autism spectrum disorder. Clin. Endocrinol. (Oxf) 67, 230-237.

Monteggia, L. M., and Kavalali, E. T. (2009). Rett syndrome and the impact of MeCP2 associated transcriptional mechanisms on neurotransmission. Biol. Psychiatry 65, 204-210.

Moy, S.S., and Nadler,J.J. (2008). Advances in behavioral genetics: mouse models of autism. Mol. Psychiatry 13, 4-26.

Moy, S. S., Nadler, J. J., Magnuson, T. R., and Crawley, J.N. (2006). Mouse models of autism spectrum disorders: the challenge for behavioral genetics. Am . J. Med. Genet. C Semin. Med. Genet. 142C, 40-51.

Nagarajan, R. P., Patzel, K. A., Martin, M., Yasui, D. H., Swanberg, S. E., Hertz-Picciotto, I., Hansen, R. L., Van De Water, J., Pessah, I. N., Jiang, R., Robinson, W. P., and Lasalle, J. M. (2008). MECP2 promoter methylation and $\mathrm{X}$ chromosome inactivation in autism. Autism Res. 1, 169-178.

Nguyen, A., Rauch, T. A., Pfeifer, G. P., and Hu, V. W. (2010). Global methylation profiling of lymphoblastoid cell lines reveals epigenetic contributions to autism spectrum disorders and a novel autism candidate gene, RORA, whose protein product is reduced in autistic brain. FASEB J. 24, 3036-3051.

Oakes, C. C., Smiraglia, D. J., Plass, C., Trasler, J. M., and Robaire, B. (2003). Aging results in hypermethylation of ribosomal DNA in sperm and liver of male rats. Proc. Natl. Acad. Sci. U.S.A. 100, 1775-1780.

Perrin, M.C., Brown, A. S., and Malaspina, D. (2007). Aberrant epigenetic regulation could explain the relationship of paternal age to schizophrenia. Schizophr. Bull. 33, 1270-1273.

Pinto, D., Pagnamenta, A. T., Klei, L., Anney, R., Merico, D., Regan, R., Conroy, J., Magalhaes, T. R., Correia, C., Abrahams, B. S., Almeida, J., Bacchelli, E., Bader, G. D., Bailey, A. J., Baird, G., Battaglia, A., Berney, T., 
Bolshakova, N., Bolte, S., Bolton, P. F., Bourgeron, T., Brennan, S., Brian, J., Bryson, S.E., Carson, A. R., Casallo, G., Casey, J., Chung, B. H. Y., Cochrane, L. Corsello, C., Crawford, E. L., Crossett, A., Cytrynbaum, C., Dawson, G., De Jonge, M., Delorme, R., Drmic, I., Duketis, E., Duque, F., Estes, A., Farrar, P., Fernandez, B. A., Folstein, S. E., Fombonne, E., Freitag, C. M., Gilbert, J., Gillberg, C., Glessner, J.T., Goldberg, J., Green, A., Green, J., Guter, S. J., Hakonarson, H., Heron, E. A., Hill, M., Holt, R., Howe, J. L., Hughes, G., Hus, V., Igliozzi, R., Kim, C., Klauck, S. M., Kolevzon, A., Korvatska, O., Kustanovich, V., Lajonchere, C. M., Lamb, J. A., Laskawiec, M., Leboyer, M., Le Couteur, A., Leventhal, B. L., Lionel, A. C., Liu, X. Q., Lord, C., Lotspeich, L., Lund, S. C., Maestrini, E., Mahoney, W., Mantoulan, C., Marshall, C. R., Mcconachie, H., Mcdougle, C. J., Mcgrath, J., Mcmahon, W. M., Merikangas, A., Migita, O., Minshew, N. J., Mirza, G. K., Munson, J., Nelson, S. F., Noakes, C., Noor, A., Nygren, G., Oliveira, G., Papanikolaou, K., Parr, J. R., Parrini, B., Paton, T., Pickles, A., Pilorge, M., Piven, J., Ponting, C. P., Posey, D. J., Poustka, A., Poustka, F., Prasad, A., Ragoussis, J., Renshaw, K., Rickaby, J., Roberts, W., Roeder, K., Roge, B., Rutter, M. L., Bierut, L. J., Rice, J. P., Salt, J., Sansom, K., Sato, D., Segurado, R., Sequeira, A. F., Senman, L., Shah, N., Sheffield, V. C., Soorya, L., Sousa, I., Stein, O., Sykes, N., Stoppioni, V., Strawbridge, C., Tancredi, R., Tansey, K., Thiruvahindrapduram, B., Thompson, A. P., Thomson, S., Tryfon, A., Tsiantis, J., Van Engeland, H., Vincent, J. B., Volkmar, F., Wallace, S., Wang, K., Wang, Z., Wassink, T. H., Webber, C., Weksberg, R., Wing, K., Wittemeyer, K., Wood, S., Wu, J., Yaspan, B. L., Zurawiecki, D., Zwaigenbaum, L., Buxbaum, J. D., Cantor, R. M., Cook, E. H., Coon, H., Cuccaro, M. L., Devlin, B., Ennis, S., Gallagher, L., Geschwind, D. H., Gill, M., Haines, J. L., Hallmayer, J., Miller, J., Monaco, A. P., Nurnberger, J. I. Jr., Paterson, A. D., Pericak-Vance, M. A., Schellenberg, G. D., Szatmari, P., Vicente, A. M., Vieland, V.J., Wijsman, E. M., Scherer, S. W., Sutcliffe, J. S., and Betancur, C. (2010). Functional impact of global rare copy number variation in autism spectrum disorders. Nature 466, 368-372.

Reichenberg, A., Gross, R., Weiser, M., Bresnahan, M., Silverman, J., Harlap, S., Rabinowitz, J., Shulman, C., Malaspina, D., Lubin, G., Knobler, H. Y., Davidson, M., and Susser, E. (2006).
Advancing paternal age and autism. Arch. Gen. Psychiatry 63, 1026-1032.

Reik, W., and Walter, J. (2001). Genomic imprinting: parental influence on the genome. Nat. Rev. Genet. 2, 21-32.

Saha, S., Barnett, A. G., Foldi, C., Burne, T. H., Eyles, D. W., Buka, S. L., and Mcgrath, J. J. (2009). Advanced paternal age is associated with impaired neurocognitive outcomes during infancy and childhood. PLoS Med. 6, e40. doi: 10.1371/journal. pmed. 1000040

Schanen, N. C. (2006). Epigenetics of autism spectrum disorders. Hum. Mol. Genet. 15, R138-R150.

Schroer, R. J., Phelan, M. C., Michaelis, R. C., Crawford, E. C., Skinner, S. A., Cuccaro, M., Simensen, R. J., Bishop, J., Skinner, C., Fender, D., and Stevenson, R. E. (1998). Autism and maternally derived aberrations of chromosome 15q. Am. J. Med. Genet. 76, 327-336.

Sebat, J., Lakshmi, B., Malhotra, D., Troge, J., Lese-Martin, C., Walsh, T., Yamrom, B., Yoon, S., Krasnitz, A., Kendall, J., Leotta, A., Pai, D., Zhang, R., Lee, Y. H., Hicks, J., Spence, S. J., Lee, A. T., Puura, K., Lehtimaki, T., Ledbetter, D., Gregersen, P. K., Bregman, J., Sutcliffe, J. S., Jobanputra, V., Chung, W., Warburton, D., King, M. C., Skuse, D., Geschwind, D. H., Gilliam, T. C., Ye, K., and Wigler, M. (2007). Strong association of de novo copy number mutations with autism. Science 316, 445-449.

Shelton, J. F., Tancredi, D. J., and HertzPicciotto, I. (2010). Independent and dependent contributions of advanced maternal and paternal ages to autism risk. Autism Res. 3, 98-98.

Smith, R. G., Kember, R. L., Mill, J., Fernandes, C., Schalkwyk, L. C., Buxbaum, J. D., and Reichenberg, A. (2009). Advancing paternal age is associated with deficits in social and exploratory behaviors in the offspring: a mouse model. PLoS ONE 4, e8456. doi: 10.1371/journal. pone. 0008456

Sparks, B. F., Friedman, S. D., Shaw, D. W., Aylward, E. H., Echelard, D., Artru, A. A., Maravilla, K. R., Giedd, J. N., Munson, J., Dawson, G., and Dager, S. R. (2002). Brain structural abnormalities in young children with autism spectrum disorder. Neurology 59, 184-192.

Strong, R., Hicks, P., Hsu, L., Bartus, R. T., and Enna, S. J. (1980). Age-related alterations in the rodent brain cholinergic system and behavior. Neurobiol. Aging 1, 59-63.

Surani, M. A. (1998). Imprinting and the initiation of gene silencing in the germ line. Cell 93, 309-312.
Szatmari, P., Paterson, A. D. Zwaigenbaum, L., Roberts, W., Brian, J., Liu, X. Q., Vincent, J. B., Skaug, J. L., Thompson, A. P., Senman, L., Feuk, L., Qian, C., Bryson, S. E., Jones, M. B., Marshall, C. R., Scherer, S. W., Vieland, V. J., Bartlett, C., Mangin, L. V., Goedken, R., Segre, A., PericakVance, M. A., Cuccaro, M. L., Gilbert, J. R., Wright, H. H., Abramson, R. K., Betancur, C., Bourgeron, T., Gillberg, C., Leboyer, M., Buxbaum, J. D., Davis, K. L., Hollander, E., Silverman, J. M., Hallmayer, J., Lotspeich, L., Sutcliffe, J. S., Haines, J. L., Folstein, S. E., Piven, J., Wassink, T. H., Sheffield, V., Geschwind, D. H., Bucan, M., Brown, W. T., Cantor, R. M., Constantino, J. N., Gilliam, T. C., Herbert, M., Lajonchere, C., Ledbetter, D. H., Lese-Martin, C., Miller, J., Nelson, S., Samango-Sprouse, C. A., Spence, S., State, M., Tanzi, R. E., Coon, H., Dawson, G., Devlin, B., Estes, A. Flodman, P., Klei, L., Mcmahon, W.M. Minshew, N., Munson, J., Korvatska, E., Rodier, P. M., Schellenberg, G. D., Smith, M., Spence, M. A., Stodgell, C., Tepper, P. G., Wijsman, E. M. Yu, C. E., Roge, B., Mantoulan, C., Wittemeyer, K., Poustka, A., Felder, B. Klauck, S. M., Schuster, C., Poustka, F., Bolte, S., Feineis-Matthews, S., Herbrecht, E., Schmotzer, G., Tsiantis, J., Papanikolaou, K., Maestrini, E., Bacchelli, E., Blasi, F., Carone, S., Toma, C., Van Engeland, H., De Jonge, M. Kemner, C., Koop, F., Langemeijer, M. Hijmans, C., Staal, W. G., Baird, G. Bolton, P. F., Rutter, M. L., Weisblatt, E. Green, J., Aldred, C., Wilkinson, J. A., Pickles, A., Le Couteur, A., Berney, T., McConachie, H., Bailey, A. J., Francis, K., Honeyman, G., Hutchinson, A. Parr, J. R., Wallace, S., Monaco, A. P., Barnby, G., Kobayashi, K., Lamb, J. A., Sousa, I., Sykes, N., Cook, E. H., Guter, S. J., Leventhal, B. L., Salt, J., Lord, C. Corsello, C., Hus, V., Weeks, D. E., Volkmar, F., Tauber, M., Fombonne, E., Shih, A., and Meyer, K. J. (2007) Mapping autism risk loci using genetic linkage and chromosomal rearrangements. Nat. Genet. 39, 319-328.

Toriello, H. V., and Meck, J. M. (2008). Statement on guidance for genetic counseling in advanced paternal age. Genet. Med. 10, 457-460.

Tsuchiya, K. J., Matsumoto, K., Miyachi, T., Tsujii, M., Nakamura, K., Takagai, S., Kawai, M., Yagi, A., Iwaki, K., Suda, S., Sugihara, G., Iwata, Y., Matsuzaki, H., Sekine, Y., Suzuki, K., Sugiyama, T., Mori, N., and Takei, N.(2008). Paternal age at birth and high-functioning autistic-spectrum disorder in offspring. Br. J. Psychiatry 193, 316-321.
Tsuchiya, K. J., Takagai, S., Kawai, M., Matsumoto, H., Nakamura, K., Minabe, Y., Mori, N., and Takei, N. (2005). Advanced paternal age associated with an elevated risk for schizophrenia in offspring in a Japanese population. Schizophr. Res. 76, 337-342.

Vestergaard, M., Mork, A., Madsen, K. M., and Olsen, J. (2005). Paternal age and epilepsy in the offspring. Eur. J. Epidemiol. 20, 1003-1005.

Weiss, L. A., and Arking, D. E. (2009). A genome-wide linkage and association scan reveals novel loci for autism. Nature 461, U802-U862.

Weiss, L. A., Shen, Y. P., Korn, J. M., Arking, D. E., Miller, D. T., Fossdal, R., Saemundsen, E., Stefansson, H., Ferreira, M. A. R., Green, T., Platt, O. S., Ruderfer, D. M., Walsh, C. A., Altshuler, D., Chakravarti, A., Tanzi, R. E., Stefansson, K., Santangelo, S. L., Gusella, J. F., Sklar, P., Wu, B., and Daly, M. J. (2008). Association between microdeletion and microduplication at 16p11.2 and autism. N. Eng. J. Med. 358, 667-675.

Xu, S., Han, J. C., Morales, A., Menzie, C. M., Williams, K., and Fan, Y. S. (2008). Characterization of 11p14p12 deletion in WAGR syndrome by array $\mathrm{CGH}$ for identifying genes contributing to mental retardation and autism. Cytogenet. Genome Res. 122, 181-187.

Zubkova, E. V., and Robaire, B. (2006). Effects of ageing on spermatozoal chromatin and its sensitivity to in vivo and in vitro oxidative challenge in the Brown Norway rat. Hum. Reprod. 21, 2901-2910.

Conflict of Interest Statement: The authors declare that the research was conducted in the absence of any commercial or financial relationships that could be construed as a potential conflict of interest.

Received: 07 April 2011; accepted: 14 June 2011; published online: 23 June 2011. Citation: Foldi CJ, Eyles DW, FlatscherBader T, McGrath JJ and Burne THJ (2011) New perspectives on rodent models of advanced paternal age: relevance to autism. Front. Behav. Neurosci. 5:32. doi: 10.3389/fnbeh.2011.00032

Copyright () 2011 Foldi, Eyles, FlatscherBader, McGrath and Burne. This is an open-access article subject to a nonexclusive license between the authors and Frontiers Media SA, which permits use, distribution and reproduction in other forums, provided the original authors and source are credited and other Frontiers conditions are complied with. 